\title{
In-Utero Transplantation of Fetal Hematopoietic Cells in the Mouse: The Effect of Donor and Recipient Gestational Maturity
}

\author{
Yoichi Takeyama, Shigeki Uehara, Kunihiro Okamura \\ and Akira Yajima \\ Department of Obstetrics and Gyneology, Tohoku University \\ School of Medicine, Sendai 980-77
}

\begin{abstract}
Takeyama, Y., Uehara, S., Okamura, K. and Yajima, A. In-Utero Transplantation of Fetal Hematopoietic Cells in the Mouse: The Effect of Donor and Recipient Gestational Maturity. Tohoku J. Exp. Med., 1997, 183 (2), 113-122To investigate the possibility of engrafting fetal liver hematopoietic cells by in utero intraperitoneal transplantation, we transplanted donor cells obtained from mouse fetuses at 13,15 and 17 days of gestation to mouse fetuses at 15, 16 and 17 days of gestation. Engraftment was assessed by Sry gene amplification of DNA extracted from peripheral blood samples of transplanted mice six weeks after birth. In comparison, we performed an in vitro colony-assay of fetal liver cells at 13, 15, and 17 days of gestation. The incidence of engraftment was significantly higher in cells of 15 days of gestation than in cells of 13 or 17 days of gestation, whereas the colony forming activity decreased gradually from 13 to 15 days of gestation. From these results, we suggest that the 15 day liver contains hematopoietic progenitors which have the specific characteristics required for engraftment by intraperitoneal transplantation. — fetal liver hematopoietic cell; in-utero transplantation; intraperitoneal transplantation; colony assay; cell differentiation (C) 1997 Tohoku University Medical Press
\end{abstract}

The fetal liver contains many hematopoietic stem/progenitor cells and plays a role as an organ of intense, but transient, hematopoietic activity (Rugh 1968). Transplantation using hematopoietic cells obtained from the fetal liver has been proposed as an alternative to bone marrow transplantation performed postnatally (Fleischman and Mintz 1979; Fleischman et al. 1982; Flake et al. 1986). When fetal liver cells are transplanted in-utero to the preimmune fetus, hematological reconstitution can be induced even after birth due to the establishment of immunological tolerance (Owen 1945; Mintz and Palm 1969). Other advantages of in-utero transplantation include: 1) low risk of graft-versus-host disease since donor cells include almost no T-cells; 2) pretreatment with irradiation and chemotherapy, which is usually performed in human bone marrow transplantation, is unnecessary since the recipient fetus is in a stage before bone marrow

Received May 7, 1997; revision accepted for publication August 27, 1997.

e-mail: vehara@ob-gy.med.tohoku.ac.jp 
hematopoiesis; and 3) the recipient having a hematological disease can be rescued prenatally and be born disease-free (Crombleholme et al. 1990, 1991; Diukman and Golbus 1992).

In animal experiments of in-utero fetal liver hematopoietic stem cell transplantation, hematopoietic chimerism has been obtained and the chimeric condition has been sustained for long periods (Fleischman and Mintz 1979; Fleischman et al. 1982; Flake et al. 1986; Harrison et al. 1989; Pallavicini et al. 1992; Zanjani et al. 1991, 1992, 1993). In human trials as well as animal experiments, there have been some reports describing engraftment of fetal liver hematopoietic stem cells in recipients suffering from thalassemia or severe combined immunodeficiency disease (Touraine 1989, 1992; Touraine et al. 1989). However, the incidences of engraftment, that is success of graft take, were not sufficiently high in those previous reports. Engraftment may fail because hematopoietic cell components gradually change when the liver is the chief organ of hematopoiesis. In the present study, therefore, we tried to prove that there is an appropriate day of gestation for the in-utero transplantation of fetal liver cells. To determine the most appropriate time frame for harvesting donor cells and for transplanting these cells to the recipient, we transplanted liver cells obtained from donor fetuses at various days of gestation to recipient fetuses of various days of gestation. Moreover, to identify the changes in hematopoietic cell components that may be induced gradually with cell differentiation, we performed colony assays of liver cells at different times of gestation.

\section{Materials and Methods}

Mice

To eliminate completely any possible immunological effect induced by allogeneic transplantation, we used the mice of only one strain (ICR strain; Charles River Japan, Yokohama).

\section{Preparation of fetal liver cells}

Three pregnant mice were sacrificed by cervical dislocation under ether anesthesia on each of 13,15 and 17 days of gestation (counting the day of positive vaginal plug as day 0 ), and their fetuses were obtained. Without regard to the gender of the fetuses, the livers were resected, minced with scissors and suspended by pipetting in phosphate-buffered saline (PBS). The donor cell suspension was filtered through nylon mesh (pore size; $50 \mu \mathrm{m}$ ) to obtain single cells. The single cell suspension was then centrifuged $(120 \times \mathrm{g}, 10$ minutes $)$ and the pellet was resuspended in PBS. Using part of the suspension, the morphological characteristics of the cells were evaluated after Giemsa staining. The concentration of cells was then determined and adjusted to $1.5 \times 10^{7}$ cells $/ \mathrm{ml}$ PBS. 


\section{Transplantation}

Nine pregnant mice of 15,16 or 17 days of gestation were laparotomized and their uteri exposed under ether anesthesia. A liver cell suspension was injected through the uterine wall into the peritoneal cavity of each fetus with an insulin injector (29 G needle; Myjector, Terumo, Tokyo). The number of donor cells transplanted was $1.6 \times 10^{6} / \mathrm{g}$ of estimated weight of the recipient fetus (the mean weight of the fetus on day 15 was $0.3 \mathrm{~g}$, that on day 16 was $0.5 \mathrm{~g}$, and that on day 17 was $0.7 \mathrm{~g}$ in the preliminary study). Thereafter, the abdominal wall of the mother mouse was closed.

\section{Assessment of donor cells engraftment}

To assess donor cell engraftment in the peripheral blood, polymerase chain reaction (PCR) was used to amplify Sry gene that is specific to mouse Y chromosomes.

The recipient mice were fed for six weeks after birth, and then only females were selected by the appearance of their external genitalia. Blood $(75 \mu \mathrm{l})$ was sampled from the caudal vein of each female mouse using capillary glass tubes. DNA was extracted from the blood samples using the Sepagene Kit (Sankojunyaku, Tokyo). The forward and reverse primers and the PCR protocol used were according to the method of Yano (1993). Briefly, amplifications were performed with $0.2 \mu \mathrm{g}$ genomic DNA, $200 \mu \mathrm{mol} /$ liter each dNTP, $0.5 \mu \mathrm{mol} / \mathrm{liter}$ each primer, $1.2 \mathrm{U}$ of Taq polymerase (Takara, Otsu) using the manufacture's buffer in a reaction volume of $40 \mathrm{ml}$. After an initial incubation of 2 minutes at $94^{\circ} \mathrm{C}$, reactions were cycled for 30 seconds at $94^{\circ} \mathrm{C}, 1$ minute at $60^{\circ} \mathrm{C}$ and 1 minute at $74^{\circ} \mathrm{C}$ for 35 cycles. Electrophoreses of the PCR products were performed in a $2 \%$ agar gel and the specific and positive control bands were detected by ethidium bromide staining. When the specific band $(147 \mathrm{bp})$ of Sry was observed, the sample was ascertained to contain cells with a $\mathrm{Y}$ chromosome and to confirm donor cell engraftment (chimerism in blood cells). Preliminary study had revealed that a Sry band could be observed in any sample of female blood containing more than $1 \%$ male blood. Engraftment rates according to each gestational day was calculated as a ratio (\%) in a number of Sry positive female recipients to that to total recipients.

\section{In vitro colony assay of fetal liver cells}

To know whether the engrafting cells of fetal liver are specific cell population, in vitro colony forming activity was examined.

The method of Namiki and Hara (1989) was followed for the in vitro colony assay. Briefly, liver cells obtained from 13, 15 and 17 day fetuses were suspended in PBS and mononuclear cells were separated over Ficoll-Conray (gravity: 1.077) using density separation techniques. Those cells were then washed in PBS, and 
$1.0 \times 10^{5}$ cells were cultured in a $35-\mathrm{mm}$ Petri dish containing $10 \%$ FCS (Flow Laboratories, Rockville, MD, USA), 0.8\% methylcellulose (Shin-etsu Kagaku, Tokyo), $3 \mathrm{U}$ erythropoietin, $100 \mathrm{U}$ interleukin-3 (IL-3) and Iscove's Modified Dulbecco's medium (IMDM, Gibco, Grand Island, NY, USA). Erythropoietin was added to stimulate erythrocyte colony-forming cells (CFC-E). IL-3 was added to stimulate pluripotent stem cells, almost every kind of progenitor cells, and many types of terminally differentiated cells. The culture condition was under $5 \% \mathrm{CO}_{2}$ in air at $37^{\circ} \mathrm{C}$ for 14 days. The number of colonies in each culture dish was thereafter counted and the morphological feature of the colony forming cells was also evaluated. In this assay, bone marrow cells derived from adult mice were cultured as control hematopoietic cells.

\section{Statistical analyses}

The chi-squared test was used to analyze statistical differences in the rates of engraftment in each donor and recipient according to the number of days of gestation. Student's $t$-tests were used to compare the number of colonies of liver cells obtained on different days of gestation and the growth ratios of different types of colonies.

\section{RESUlts}

\section{Morphological typing of donor cells by Giemsa staining}

Cell suspensions from each of 13,15 , and 17 days of gestation contained the erythroid progenitors in substantial numbers, while they contained few of the other progenitors.

\section{Amplification of Sry gene to assess engraftment}

Some of the fetuses that were intraperitoneally injected were stillborn. To determine if the graft had taken, peripheral blood samples of 91 female mice were examined by PCR amplification of Sry. The positive band was found in 16 of 91 $(17.6 \%)$ samples (Fig. 1), and donor cell engraftment (chimerism in blood cells) was ascertained to have been achieved in those female mice.

Engraftment rates in transplants according to the donor and recipient days of gestation

The results of engraftment are summarized in Table 1 . The analyses of donor and recipient fetuses according to gestational day, the rate in the 15-day donor and 15-day recipient group was $30.8 \%(4 / 13)$, in the 15-day donor and 16-day recipient group it was $25.0 \%(4 / 16)$, and in the 15-day donor and 17-day recipient it was $42.9 \%(6 / 14)$. In the other groups, little or no engraftment was detected. There were significant $(p<0.01)$ differences between the ratio obtained in 15-day donors and the ratios obtained in 13- and 17-day donors. In contrast to the differences related to donor age, the comparisons of engraftment rates did 


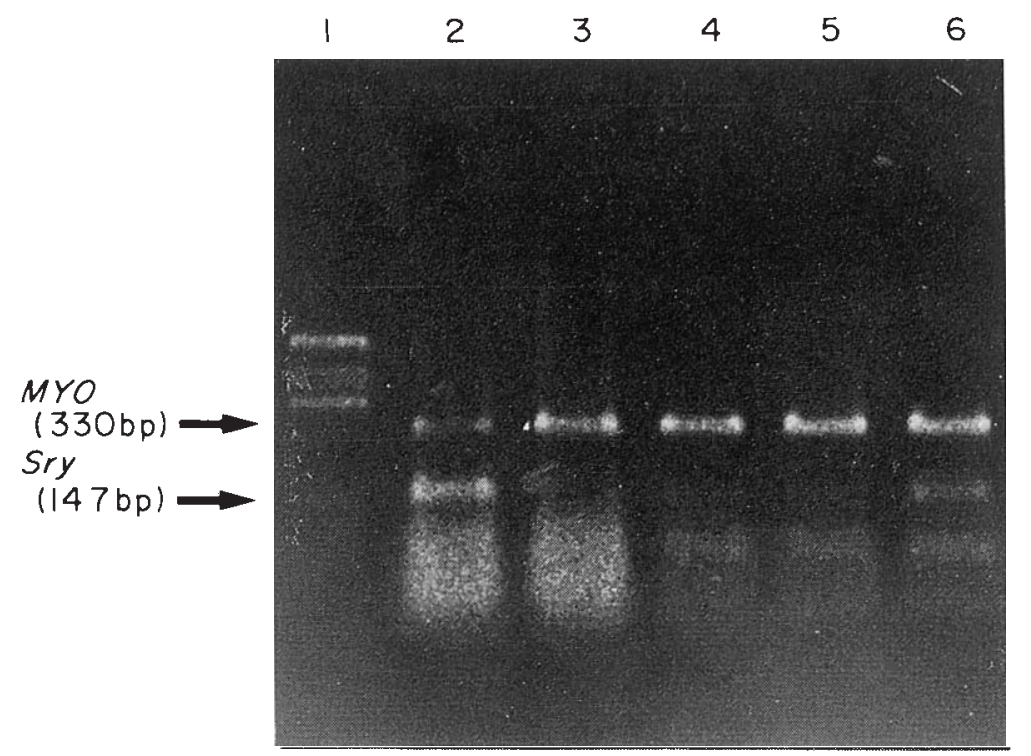

Fig. 1. Agarose gel electrophoresis pattern with ethidium bromide staining. When a positive Sry band of $147 \mathrm{bp}$ was observed, donor cells engraftment (chimerism in blood cells) was ascertained. Lane 1: pHY marker, Lane 2: male control, Lane 3: female control, Lane 4-6: samples. A positive Sry band is observed on Lane 6. MYO: control band of myosin gene.

TABLE 1. Engraftment rates of fetal liver cells

\begin{tabular}{ccccc}
\hline \multirow{2}{*}{$\begin{array}{c}\text { Day of gestation in } \\
\text { recipient fetuses }\end{array}$} & \multicolumn{2}{c}{ Day of gestation in donor fetuses } & \multirow{2}{*}{ Total } \\
\cline { 2 - 4 } 15 & 13 & 15 & 17 & \\
\hline \multirow{2}{*}{16} & $0 / 10$ & $4 / 13$ & $0 / 11$ & $4 / 34$ \\
& $0 \%$ & $30.8 \%$ & $0 \%$ & $11.8 \%$ \\
17 & $1 / 7$ & $4 / 16$ & $1 / 8$ & $6 / 31$ \\
& $14.3 \%$ & $25.0 \%$ & $12.5 \%$ & $19.4 \%$ \\
\multirow{2}{*}{ Total } & $0 / 6$ & $6 / 14$ & $0 / 6$ & $6 / 26$ \\
& $0 \%$ & $42.9 \%$ & $0 \%$ & $23.1 \%$ \\
& $1 / 23$ & $14 / 43$ & $1 / 25$ & $16 / 91$ \\
& $4.3 \%$ & $32.6 * \cdots * \cdots \cdots$ & $4.0 \%$ & $17.6 \%$
\end{tabular}

$* *$ Significant difference $(p<0.01)$

not vary with recipient age.

Number of colonies and ratios of colony types formed by liver cells according to gestational day

In the in vitro colony assay three types of colonies grew after 14 days cultures of fetal liver cells obtained on each gestational day (Fig. 2). One type of colony consisted of only small cells (small cell type). Another consisted of colonies formed by only large cells (large cell type). The remaining colonies involved small and large cells (mixed type). 

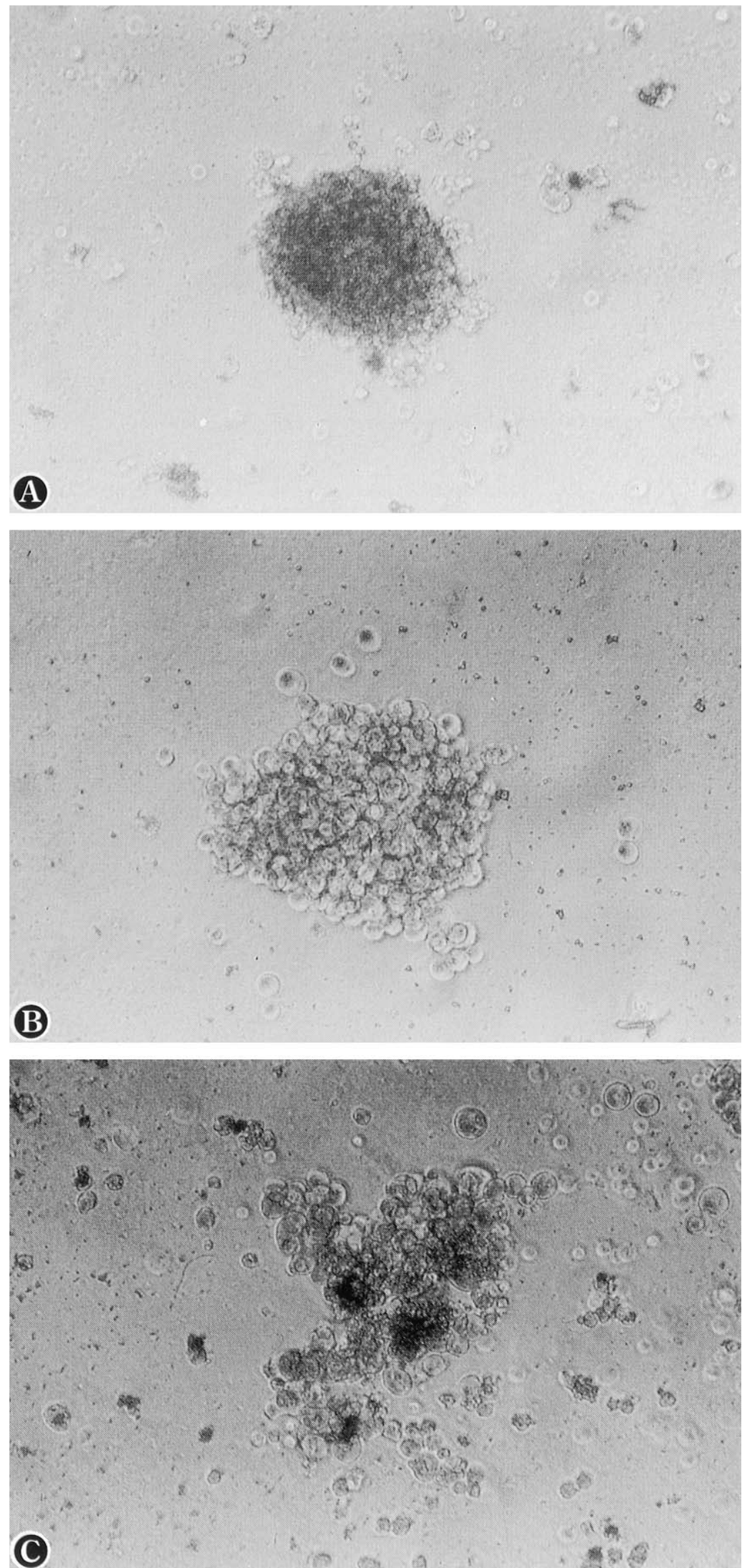

Fig. 2. 
The total number of colonies originating from liver cells obtained on different days of gestation and from adult bone marrow cells are summarized in Fig. 3 with the ratios of the three types of colonies. 13-Day cells formed the most colonies and 15-day cells formed the second most, however, the difference between the two numbers was small. As gestation progressed further, colony formation decreased and the colony number of 17-day cells was limited to the number of bone marrow cells. Significant $(p<0.05)$ differences in total colony numbers were observed between 13- and 17-day cells, and between 15- and 17-day cells. As shown in Fig. 3 , the ratios of the three colony types slightly differred according to gestational day, but no significant differences were observed in comparisons of these colony ratios.

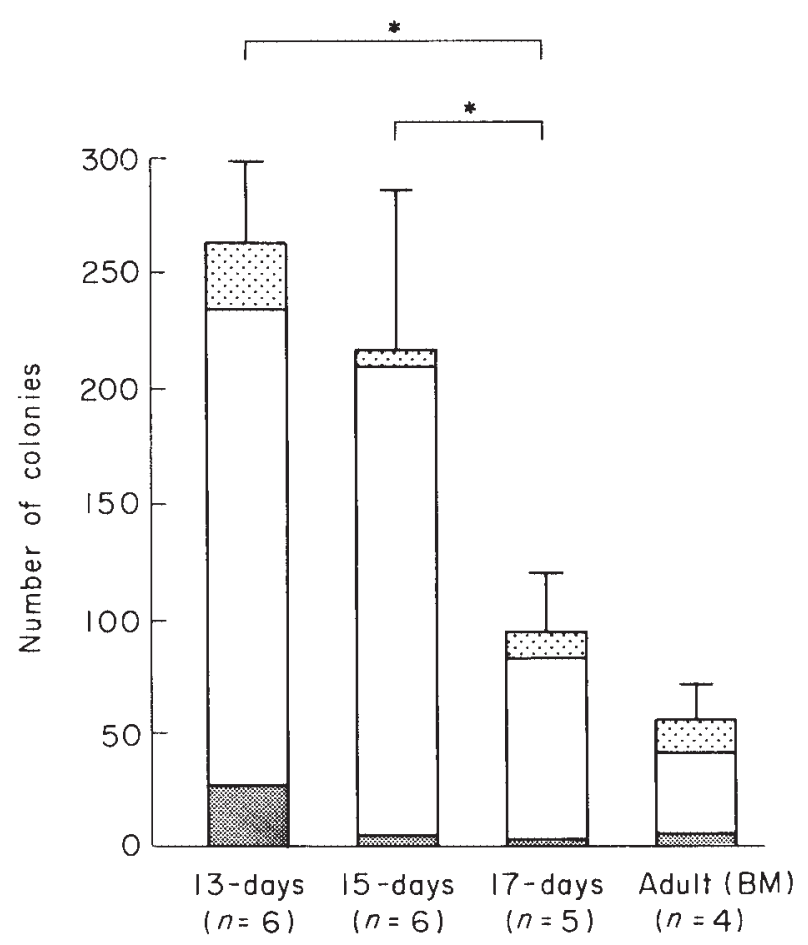

Fig. 3. Number of colonies and the ratios of the three types of colonies obtained from fetal livers of 13,15 and 17 days of gestation and adult bone marrows. The whole bar represents the mean total number of colonies \pm the standard deviation. The dotted area ( $\mathrm{a})$ represents the mean ratio of small cell colonies, the open area $(\square)$ denotes the mean ratio of large cell colonies, and the black area (图) denotes the mean ratio of mixed colonies. Significant differences are shown by asterisks $\left({ }^{*} p<0.05\right)$. 13-Day cells exhibited the highest activity of colony formation and 15-day cells did the second highest activity. The activity of 17-day cells was significantly lower than that of the former two groups and was the same as that of adult bone marrow cells. No significant differences were observed in comparisons of ratios of the three types of colonies. BM: adult bone marrow

Fig. 2. Colony formation by fetal liver cells obtained at 13,15 and 17 days gestation in an in vitro colony assay. Fetal liver cells obtained on each gestation day formed three different types of colonies. A: colonies of the small cell type involve only small cells. B: colonies of the large cell type involve only large cells. C: colonies of the mixed type involve small and large cells. 


\section{Discussion}

The mouse liver begins hematopoiesis at 11 days of gestation and plays a role as the most active hematopoietic organ until 17 days of gestation (Rugh 1968). Since the hematopoietic cell components change gradually during liver hematopoiesis (Rugh 1968), it is likely that engraftment rates may change according to the donor's gestational age. Our present result suggests that only the 15-day fetal mouse liver can provide appropriate donor cells in the optimum stage of differentiation for engraftment in-utero by intraperitoneal transplantation.

In-utero transplantation of mouse fetal liver cells to mouse fetuses was described by Fleischman and Mintz (1979) and Fleischman et al. (1982). They attempted transplantation in-utero by microinjection of liver cells obtained on 13 to 15 days of gestation into blood vessels of the fetal placenta. Suggesting that the transplanted cells entered the fetal circulation and replaced the erythroid lineage in recipient mice having genetic anemia, they found the procedure to be effective. Their reports and the present study differ with respect to method and transplantation site. After intravascular injection of liver cells, cells directly enter the fetal circulation, migrate to the bone marrow, and proliferate. However, for engraftment after intraperitoneal injection, transplanted cells must first penetrate the vessel. This means that the engrafted cells must be able to enter the vessel. Since adhesion molecules, such as selectins, integrins, vascular adhesion molecules, and others, play a role in vessel penetration by some blood cells (Alberts et al. 1994), it is possible that some live hematopoietic cells express such adhesion molecules transiently during liver hematopoiesis, although we have not examined the detailed mechanism.

Copp and Cockroft (1990) described the one factor which affects engraftment being the colony proliferating activity of the transplanted cells. Therefore, we examined colony proliferation activity of fetal liver cells obtained on each gestational day. The colony forming activity gradually decreased from 13 to 15 days of gestation, whereas the engraftment rate of donor cells obtained on 13 days of gestation was significantly lower than that of donor cells obtained on 15 days of gestation. Therefore, it is suggested that engraftment rate does not relate to colony forming activity. In contrast to the fetal liver cells of mice, previous successful reports of engraftment after intraperitoneal transplantation of fetal liver cells involved donor sheep of 35 to 50 days of gestation (Flake et al. 1986) and 48 to 54 days of gestation (Zanjani et al. 1992), donor monkeys of 59 to 68 days of gestation (Harrison et al. 1989), and donor human abortuses of 9 weeks of gestation (Touraine et al. 1989), 13 to 15 weeks of gestation (Zanjani et al. 1993) and 15 to 18 weeks of gestation (Pallavicini et al. 1992). Since these species have a relatively long gestational period, their fetal livers can provide cells which are appropriate for intraperitoneal injection for a relatively longer duration than possible with the fetal liver of mouse. 
In contrast to the gestational day of the donor cells, the gestational day of the recipient fetuses (from 15 to 17 days of gestation) did not affect engraftment of hematopoietic cells in the present study. Fleischman and Mintz (1979) and Fleischman et al. (1982) employed mice of 11 days of gestation and Pallavicini et al. (1992) employed mice of 11 to 13 days of gestation as the recipient fetuses and obtained engraftment. Therefore, mouse fetuses can take grafts during a relatively long gestational period.

Finally, the rate of engraftment was limited to less than $42.9 \%$ even when donor cells were obtained from the liver of 15 days of gestation. This success rate may be too small for clinical trials. Moreover, six weeks after transplantation may be too short a time to evaluate long term engraftment. These issues require further investigation.

\section{References}

1) Alberts, B., Bray, D., Lewis, J., Raff, M., Roberts, K. \& Watson, J.D. (1994) Molecular Biology of the Cell. 3rd ed., Garland Publishing, New York.

2) Copp, A.J. \& Cockroft, D.L. (1990) Postimplantation Mammalian Embryos. Oxford University Press, Oxford, pp. 75-77.

3) Crombleholme, T.M., Harrison, M.R. \& Zanjani, E.D. (1990) In utero transplantation of hematopoietic stem cells in sheep: The role of $\mathrm{T}$ cells in engraftment and graft-versus-host disease. J. Pediat. Surg., 25, 885-892.

4) Crombleholme, T.M., Langer, J.C., Harrison, M.R. \& Zanjani, E.D. (1991) Transplantation of fetal cells. Am. J. Obstet. Gynecol., 164, 218-230.

5) Diukman, R. \& Golbus, M.S. (1992) In utero stem cell therapy. J. Reprod. Med., 37, $515-520$.

6) Flake, A.W., Harrison, M.R., Adzick, N.S. \& Zanjani, E.D. (1986) Transplantation of fetal hematopoietic stem cells in utero: The creation of hematopoietic chimeras. Science, 233, 776-778.

7) Fleischman, R.A. \& Mintz, B. (1979) Prevention of genetic anemias in mice by microinjection of normal hematopoietic stem cells into the fetal placenta. Proc. Natl. Acad. Sci. USA, 76, 5736-5740.

8) Fleischman, R.A., Custer, R.P. \& Mintz, B. (1982) Totipotent hematopoietic stem cells: Normal self-renewal and differentiation after transplantation between mouse fetuses. Cell, 30, 51-359.

9) Harrison, M.R., Crombleholme, T.M., Tarantal, A.F., Slotnick, R.N., Golbus, M.S. \& Zanjani, E.D. (1989) In utero transplantation of fetal hematopoietic stem cells in monkeys. Lancet, 2, 1425-1427.

10) Mintz, B. \& Palm, J. (1969) Gene control of hematopoiesis. I. Erythrocyte mosaicism and permanent immunological tolerance in allophenic mice. J. Exp. Med., 129, 1013-1027.

11) Namiki, M. \& Hara, H. (1989) Enhancement of colony-forming activity of granulocyte-macrophage colony-stimulating factor by monocytes in vitro. Blood, 74, 918-924.

12) Owen, R.D. (1945) Immunogenetic consequences of vascular anastomoses between bovine twins. Science, 102, 400-401.

13) Pallavicini, M.G., Flake, A.W., Madden, D., Bethel, C., Duncan, B., Gonzalgo, M.L., Haendel, S., Montota, T. \& Robert, L. (1992) Hemopoietic chimerism in rodents transplanted in utero with fetal human hemopoietic cells. Transplant. Proc., 24, 542543. 
14) Rugh, R. (1968) Its reproduction and development. In: The Mouse, Burgess Publishing Co., Minneapolis, pp. 262-265 and pp. 272-275.

15) Touraine, J.L. (1989) New strategies in the treatment of immunological and other inherited diseases: Allogeneic stem cells transplantation. Bone Marrow Transplant., 4, Suppl., 139-141.

16) Touraine, J.L. (1992) Transplantation of fetal haemopoietic and lymphopoietic cells in humans, with special reference to in utero transplantation. In: Fetal Tissue Transplants in Medicine, edited by R.G. Edwards, Cambridge University Press, Cambridge-New York-Victoria, pp. 155-177.

17) Touraine, J.L., Raudrant, D., Royo, C., Rebaud, A., Roncarolo, M.G., Souillet, G., Philippe, N., Touraine, F. \& Betuel, H. (1989) In-utero transplantation of stem cells in bare lymphocyte syndrome. Lancet, 1, 1382.

18) Yano, T. (1993) Sexing of in vitro-fertilized preimplantation mouse embryos by the PCR method. Jpn. J. Hum. Genet., 38, 277-288.

19) Zanjani, E.D., Roy MacKintosh, F. \& Harrison, M.R. (1991) Hematopoietic chimerism in sheep and nonhuman primate by in utero transplantation of fetal hematopoietic stem cells. Blood Cells, 17, 349-363.

20) Zanjani, E.D., Pallavicini, M.G., Ascensao, J.L., Flake, A.W., Langlois, R.G., Reitsma, M., Roy MacKintosh, F., Stutes, D., Harrison, M.R. \& Tavassoli, M. (1992) Engraftment and long-term expression of human fetal hematopoietic stem cells in sheep following transplantation in utero. J. Clin. Invest., 89, 1178-1188.

21) Zanjani, E.D., Ascensao, J.L. \& Tavassoli, M. (1993) Liver-derived fetal hematopoietic stem cells selectively and preferentially home to the fetal bone marrow. Blood, 81, 399-404. 